\title{
Measuring Workplace Bullying: Reliability and Validity of the Japanese Version of the Negative Acts Questionnaire
}

\author{
Kanami Tsuno ${ }^{1-3}$, Norito KawaKami ${ }^{2,3}$, Akiomi Inoue ${ }^{1,2}$ and Kiyoko AbE ${ }^{4}$ \\ ${ }^{1}$ Japan Society for the Promotion of Science, ${ }^{2}$ School of Health Sciences and Nursing, ${ }^{3}$ School of Public Health, \\ Graduate School of Medicine, The University of Tokyo and ${ }^{4}$ Institute for Graduate Nurses, Japanese Nursing \\ Association, Japan
}

\begin{abstract}
Measuring Workplace Bullying: Reliability and Validity of the Japanese Version of the Negative Acts Questionnaire: Kanami Tsuno, et al. Japan Society for the Promotion of ScienceObjectives: Workplace bullying is increasingly being recognized as a serious problem within the work environment. Previous studies in European countries have reported the prevalence of workplace bullying and its association with poor mental health, using the Negative Acts Questionnaire-Revised (NAQ-R: Einarsen \& Hoel, 2001), but there have been very few studies in Japan. The authors translated the 22-item $N A Q-R$ into the Japanese language and examined the internal consistency reliability and concurrent and construct validity, including factor-based validity, of this scale in a sample of Japanese civil servants. Methods: A total of 830 males and 796 females were surveyed, using anonymous questionnaires including the NAQ$\mathrm{R}$, Leymann Inventory of Psychological Terror (LIPT), and scales for interpersonal relations at work and psychological distress (response rate, $46.7 \%$ ). Results: Cronbach's alpha coefficients of the internal consistency reliability of the NAQ-R were high (0.910.95 ) for males and females. Workplace bullying measured by the NAQ-R was strongly associated with that measured by the LIPT and other scales on workplace bullying. The NAQ-R was associated with high psychological distress, high intragroup and intergroup conflict, low supervisor and coworker support, and low interactional justice, as expected. Although three factors were extracted, this findings differed slightly from the factor structure previously reported (Einarsen et al., 2009). However, Factor 1 explained most of the variance, indicating that a one
\end{abstract}

Received Mar 14, 2010; Accepted May 23, 2010

Published online in J-STAGE Jun 21, 2010

Correspondence to: K. Tsuno, School of Health Sciences and Nursing, Graduate School of Medicine, The University of Tokyo, 7-3-1 Hongo, Bunkyo-ku, Tokyo 113-0033, Japan (e-mail: ktsunotky@umin.ac.jp) factor structure fitted the data better. Conclusion: The present study showed acceptable levels of reliability and validity of the Japanese version of the NAQ-R among Japanese civil servants.

(J Occup Health 2010; 52: 216-226)

Key words: Cross-sectional study, Harassment at work, Mobbing, Prevalence, Scale development, Workplace bullying

Workplace bullying is increasingly recognized as a serious problem within the work environment. The concept of workplace bullying, sometimes referred to as workplace harassment ${ }^{1)}$, or workplace abuse ${ }^{2)}$, was described by the Swedish researcher Heinz Leymann for the first time in 1984; he named this phenomenon "mobbing" or "psychological terror $^{3) "}$. Leymann ${ }^{3)}$ defined workplace bullying as hostile and unethical communication that occurs on a very frequent basis (statistical definition: at least once a week) and over a long period of time (statistical definition: at least six months of duration). Following Leymann definition, Einarsen et $a l .{ }^{4}$ proposed a slightly different definition, with less strict criteria for the frequency and duration, and nowadays this has been widely employed in the literature.

Until now, especially in European countries, many researchers have reported the prevalence of bullying at work. For instance, 3.6-16\% of the workforce in Europe is found to be exposed to some kind of bullying at the workplace weekly or more ${ }^{3,5-9}$. At the same time, research has shown that bullying at work positively associated with health outcomes: depressive symptoms ${ }^{10)}$, post-traumatic stress disorder symptoms ${ }^{11)}$, psychological and psychosomatic health complaints ${ }^{12)}$, newly diagnosed fibromyalgia ${ }^{13)}$, and use of sleepinducing drugs ${ }^{14)}$. It has also been related to staff turnover and cases of sick leave ${ }^{15,16)}$.

Generally, researchers have employed one or two different method(s) to assess the prevalence of bullying. One method, which might be termed a "subjective" 
method $^{17)}$, requires respondents to indicate whether they feel exposed to bullying at work, on the basis of the definition of workplace bullying. The other method, the "operational" method, measures the frequency at which respondents have been subjected to various types of negative acts during the previous six months. This method does not require the respondents to label these behaviors as bullying, which appears less likely to prompt the respondent's cognitive or emotional processing ${ }^{18)}$. For this reason, the authors decided to use the operational method mainly in this study.

To measure workplace bullying with the "operational" method, two measures have been used most widely in research. One is the Leymann Inventory of Psychological Terror (LIPT) ${ }^{3)}$, which comprises 45 categories of acts of bullying. The LIPT was designed as a diagnostic tool to identify victims of severe bullying who are likely to be traumatized from their experience, based on the Leymann definition. This scale evaluates the 12-month prevalence of exposure to 45 forms of bullying. The other scale is the Negative Acts Questionnaire (NAQ) ${ }^{6}$ ) and its revised version (Negative Acts Questionnaire-Revised: NAQR) ${ }^{19,20)}$, both of which consist of 22 items of negative acts. The NAQ is based on the definition of Einarsen $e t$ $a l$. and was created as a survey instrument with the aim of establishing a reliable, valid, comprehensive, yet relatively short scale for use in a variety of occupational settings ${ }^{21}$. It has now been used in about 40 countries. A later version of NAQ, i.e., the NAQ-R ${ }^{19}{ }^{20)}$, which was developed and refined based on the original scale ${ }^{6,18,22)}$, initially included 29 items describing negative acts that were personal as well as work-related ${ }^{20,23)}$; later, the number of the items reduced to $22^{8,19)}$.

In studies in Norway, the NAQ-R has been shown to have acceptable internal consistency reliability (Cronbach's alpha coefficient ranged from $0.88-0.90)^{8,24)}$. Additionally, it has been reported that high scores on the NAQ-R were correlated with poor mental health, high psychosomatic complaints, low performance, increased sickness absenteeism, and greater inclination to leave one's job ${ }^{21)}$. A previous study also reported that the NAQ-R correlated with high work pressure from workload, poor organizational climate, negative relationships with colleagues, low organizational commitment, and low organizational satisfaction $^{21}$. Although other scales have been developed to measure workplace bullying ${ }^{25,26)}$, most have been used in only a limited number of studies ${ }^{41)}$ or their validity and reliability are unknown ${ }^{25}$.

The NAQ-R shows high internal consistency and construct validity; however, its psychometric property has been tested only within European countries. In Japan, social concern about workplace bullying has increased since a Tokyo District Court judged an employee's depression and suicide, caused by his superior's bullying, as an occupational injury in October 2007. However, there are very few studies that have reported the prevalence of workplace bullying and its impact on health in Japan ${ }^{27,28)}$, which is partly attributable to a lack of scientifically-valid measurements of workplace bullying in Japan. While a Japanese version of the $\mathrm{NAQ}^{6}$ has been developed ${ }^{28)}$, the Bergen Bullying Research Group, a research team at the University of Bergen in Norway that distributes and promotes the NAQ and NAQ-R, now recommends the use of NAQ-R, instead of NAQ (Nielsen, personal communication). The Japanese version of the NAQ-R was developed as a doctoral thesis ${ }^{27)}$, but the translated scale was designed specially for nurses and can not be used for the general working population. Japan and other Asian countries have distinct features of workplace structure, being more vertical, collective, and hierarchy-oriented ${ }^{29)}$ than in European countries ${ }^{30)}$, which could result in a greater prevalence of workplace bullying. Also, patterns of workplace bullying may be different among countries, as suggested by different factor structures of the NAQ found among studies ${ }^{6,18)}$. The development of a new Japanese version of the NAQ-R for the general working population would contribute not only to research on workplace bullying in Japan, but also to the global understanding of this psychosocial hazard at work.

The authors developed a Japanese version of the NAQ$\mathrm{R}$ for the general working population, revising the previous Japanese version of NAQ-R for nurses ${ }^{27)}$. The purpose of this study was to examine the internal consistency reliability and concurrent and construct validity, including factor-based validity, of this scale using a sample of Japanese civil servants.

\section{Participants and Methods}

\section{Participants}

A cross-sectional study was conduced of civil servants at seven workplaces consisting of six city offices and one other civil service office of local governments in the Kanto region in Japan in March 2009. A total of 4,072 anonymous questionnaires were distributed through labor unions, with a letter describing the aims and procedure of the study assuring that the survey was anonymous and no individual would be identified in analyzing and reporting the data. A total of 2,194 questionnaires were returned sealed in envelopes, providing a response rate of $46.7 \%$. After excluding employees who had at least one missing entry in the questionnaire, the final number of respondents including the analysis was 1,626 (830 males and 796 females). The study procedure was approved by the Ethics Committees of the Graduate School of Medicine, The University of Tokyo.

\section{Measurements}

Japanese version of the NAQ-R

The NAQ- ${ }^{8,19)}$ has 22 items, measuring how often during the previous six months respondents have been 
subjected to various negative acts, which when occurring on a frequent basis might be considered as bullying ${ }^{18)}$. All items in the NAQ-R are described without reference to the word "bullying" or "harassment". This has the advantage of letting the participants respond to each item without having to label and identify it as bullying before answering ${ }^{31)}$. The NAQ-R contains items referring to personal bullying, work-related bullying, and physical intimidation behaviors ${ }^{21)}$. Response categories are: "Never," "Now and then," "Monthly," "Weekly," and "Daily" (range, 1-5). In the present study, a sum-scale of the NAQ-R was used in the statistical analyses of the relationships between exposure to bullying behaviors and interpersonal relations at work and psychological distress. In this study, weekly or more exposure to at least one negative act for the previous six months, according to the "operational" criteria put forward by Leymann ${ }^{3)}$, was defined as bullying.

Also, "subjective" criteria based on a single item from the NAQ-R were used. In the NAQ-R, the employees were asked a question after being given the following definition of bullying: "We define bullying as a situation where one or several individuals persistently over a period of time perceive themselves to be on the receiving end of negative acts from one or several persons, in a situation where the target of bullying has difficulty in defending him or herself against these acts. We will not refer to a one-off incident as bullying." The employees were asked whether or not they perceived themselves as being bullied within the past six months. Response categories are: "No," "Yes, but only rarely," "Yes, now and then," "Yes, several times a week," and "Yes, almost daily." Those who answered "yes" to this question were categorized as self-labeling of victims of bullying at work (NAQ-R ver.) in this study as well as previous studies ${ }^{7,8)}$.

The English version of the NAQ-R was translated into Japanese and modified, using plain Japanese language expressions, by the authors. Then, the first translated version was tested with a group of nine occupational health staff (i.e., industrial physicians, occupational health nurses, and clinical psychologists) to receive their feedback, and revised accordingly.

In addition, the second version was back-translated and sent to the Bergen Bullying Research Group whose feedback led to a small amendment to one item of the Japanese NAQ-R of the second version (the item \#17, "Having allegations made against you"). In the second version, the word "allegations" was translated as "suspicion," which has a different meaning than the original version. In the final version, the word was translated as "blame." While the amendment might have a small influence on the properties of the scale, it might affect the results of the structure of the scale to some extent. The back-translated NAQ-R was exactly the same as the original version. This revised final version of the
NAQ-R was used in the present study (see Appendix).

\section{Other Measures}

1) LIPT for workplace bullying

To test the construct validity of the NAQ-R, another scale of workplace bullying was also measured: the French version of the LIPT ${ }^{3)}$ has 45 items measuring the experience of bullying within the previous $12 \mathrm{mo}$, with a two-point response option $(0=n o ; 1=y e s)$. The frequency and duration of bullying were both assessed by one question, also used by Leymann ${ }^{3}$. To measure exposure to bullying operationally, the Leymann definition, i.e., exposure to at least one form of bullying within the previous 12 mo, weekly or more, and for at least six months, was also used. At the same time, a total score of 45 items of the LIPT was calculated as an indicator of workplace bullying. This scale was translated into Japanese and modified in the same manner as the Japanese version of the NAQ-R. Also, an alternative subjective criterion of bullying based on a single-item from the LIPT was used. In the LIPT, the employees were asked a question after being given the following definition of bullying: "Bullying may be defined by a situation in which someone is exposed to hostile behavior on the part of one or more persons in the work environment which aim continually and repeatedly to offend, oppress, maltreat, or to exclude or isolate over a long period of time." The employees were asked whether or not they perceived themselves as being exposed to bullying within the past 12 mo. Response categories were "yes" and "no." Those who endorsed this question were categorized selflabeling of victims of bullying at work (LIPT ver.) in this study.

2) Psychological distress

Psychological distress was measured by the Japanese version of the K6 scale ${ }^{32)}$ which consists of six items asking how frequently respondents have experienced symptoms of psychological distress during the past 30 days.

3) Interactional justice

Interactional justice was measured by the Japanese version of the Organizational Justice Questionnaire ${ }^{33-35)}$, which includes six items assessing the degree of fairness and consideration for subordinate workers in the behavior of the respondent's supervisor at work. The total score for this scale was calculated by averaging item scores.

4) Intragroup and intergroup conflict

Intragroup and intergroup conflict were measured by the shortened Japanese version of the Scales of Interpersonal Conflict at Work ${ }^{36)}$, which was adapted from the National Institute for Occupational Safety and Health Generic Job Stress Questionnaire (NIOSH-GJSQ).

5) Worksite social support

Worksite social support was measured by the Japanese version of the Job Content Questionnaire (JCQ) ${ }^{37)}$, which 
includes questions about worksite support from supervisors and co-workers.

6) Demographic variables

Demographic and occupational variables were assessed by a questionnaire developed by the authors. The demographic variables included sex and age; occupational variables included occupational status (manager, whitecollar worker, blue-collar worker, human service worker, or others) and employment contract (regular, contingency, or part-time).

\section{Statistical analysis}

In order to know the sex difference in the scores of the NAQ-R, the average scores, as well as those of the other scales and distributions of demographic variables, were compared by sex. To examine internal consistency reliability, Cronbach's alpha coefficient was calculated for the Japanese version of the NAQ-R. To test structural validity, all 22 items were entered into an exploratory factor analysis, using the maximum likelihood method. In the exploratory factor analysis, factors with eigenvalues of more than 1.0 were extracted and the promax rotation method was used to obtain factor structures. Based on earlier research and theoretical notions ${ }^{21}$, three underlying factors were expected: person-related bullying, workrelated bullying, and physical intimidation. Also, previous studies reported a one-factor model and a twofactor model (a person-related bullying and a work-related bullying $)^{19)}$. In this study, the authors tested a one-factor model (Model 1), a two-factor model (Model 2), and a three-factor model (Model 3). Model fit was assessed using a combination of fit indices including the goodness of fit index (GFI), the adjusted goodness fit index (AGFI), the comparative fit index (CFI), and the root mean square error of approximation (RMSEA). The acceptability of model fit was judged by the following criteria: GFI, AGFI, and CFI $>0.90$ and RMSEA $<0.05^{38)}$.

To assess construct validity, Pearson's correlation coefficients were calculated between the total score of the NAQ-R and three groups of variables: indicators of bullying (the number of bullying behaviors measured by the LIPT, and self-labeling as a victim of bullying measured by LIPT and NAQ-R), interpersonal relations at work (intragroup conflict, intergroup conflict, supervisor support, co-worker support, and interactional justice), and psychological distress. These variables were also compared between participants who had experienced at least one negative act weekly or daily and of monthly or less, using $t$-test and ANCOVA. The score and classification base on the NAQ-R were reasonably expected to be positively associated with the other indicators of bullying and with psychological distress ${ }^{10-12}$. Intragroup conflict and intergroup conflict were expected to be positively associated with the NAQ-R indicators, because workplace bullying is an exaggerated form of interpersonal conflict ${ }^{3)}$; supervisor support, co-worker support, and interactional justice were expected to be negatively associated with the NAQ-R indicators, because victims of workplace bullying could have a lowered perception of receiving social support from workplace members and particularly of being fairly treated by a supervisor, as interactional injustice was found to be the strongest predictor of aggression among the factor of organizational injustice ${ }^{39,40)}$. The level of significance used was 0.05 (two-tailed). SPSS 17.0J and Amos 16.0J for Windows were used for the statistical analyses.

\section{Results}

Characteristics of respondents

Table 1 shows the respondents' characteristics and average scores on each scale. Of the respondents, $51.0 \%$ were male and $49.0 \%$ were female.

\section{Reliability of the NAQ-R}

Cronbach's alpha coefficients of the internal consistency reliability of the NAQ-R were 0.95 and 0.91 for males and females, respectively (Table 1).

\section{Factor structure of $N A Q-R$}

The exploratory factor analysis yielded a three-factor model (hereafter referred to as Model 4), which consisted of a different factor-structure from models previously reported (Table 2). Eight of the twelve items for personrelated bullying and six of eight items for work-related bullying showed the greatest factor loading on Factor 1. Factor 2 consisted of some items of person-related bullying (two items) and physical intimidation bullying (one item). Factor 3 consisted of two items mainly concerning assignment of work with lower responsibility and competence.

The confirmatory factor analysis showed non-optimal fits for all of the models (GFI=0.83 for Model 1, 0.86 for Model 2, 0.84 for Model 3, and 0.86 for Model 4; AGFI $=0.80$ for Model 1, 0.83 for Model 2, 0.81 for Model 3, and 0.83 for Model 4; CFI=0.84 for Model 1, 0.87 for Model 2, 0.85 for Model 3, 0.87 for Model 4; and RMSEA=0.096 for Model 1, 0.089 for Model 2, 0.094 for Model 3, and 0.087 for Model 4).

\section{Concurrent and constructive validity of the NAQ-R}

As shown in Table 3, higher levels of NAQ-R score were positively and significantly correlated with selflabeling as a victim of workplace bullying as measured by the NAQ-R and LIPT, the number of bullying behaviors measured by the LIPT, intragroup and intergroup conflict, and psychological distress $(p<0.001)$. Higher levels of NAQ-R score were also negatively and significantly correlated with supervisor and co-worker support, and interactional justice $(p<0.001)$.

Table 4 shows that participants who had experienced more than one of the 22 negative acts listed in the NAQ- 
Table 1. Distribution of demographic characteristics, workplace bullying, interpersonal relations at work, and psychological distress among civil servants who participated in the study by sex $(\mathrm{N}=1,626)$

\begin{tabular}{|c|c|c|c|c|c|}
\hline & \multicolumn{2}{|c|}{ Male $(\mathrm{N}=830)$} & \multicolumn{2}{|c|}{ Female $(\mathrm{N}=796)$} & \multirow[t]{2}{*}{$p \ddagger$} \\
\hline & Average $(\mathrm{SD}) \dagger$ & $\mathrm{n}(\%)$ & Average $(\mathrm{SD})^{\dagger}$ & $\mathrm{n}(\%)$ & \\
\hline Age (years) & $43.0(9.8)$ & & $42.1(10.7)$ & & 0.072 \\
\hline Occupational status & & & & & $<0.001$ \\
\hline Manager & & $93(11.2)$ & & $27(3.4)$ & \\
\hline White-collar & & $540(65.1)$ & & $223(28.0)$ & \\
\hline Blue-collar & & $152(18.3)$ & & $99(12.4)$ & \\
\hline Human service workers & & $29(3.5)$ & & $396(49.7)$ & \\
\hline Others & & $16(1.9)$ & & $51 \quad(6.4)$ & \\
\hline Employment contract & & & & & $<0.001$ \\
\hline Regular employment & & $822(99.0)$ & & $753(94.6)$ & \\
\hline Contingency/part-time worker & & $8(1.0)$ & & $43 \quad(5.4)$ & \\
\hline Scale scores (possible range) $\S$ & & Cronbach's $\alpha$ & & Cronbach's $\alpha$ & \\
\hline Workplace bullying (NAQ-R: 23-115) & $25.6(8.3)$ & 0.95 & $25.3(6.4)$ & 0.91 & 0.520 \\
\hline Workplace bullying (LIPT: 0-45) & $1.2(4.1)$ & 0.95 & $1.2(3.2)$ & 0.91 & 0.943 \\
\hline Intragroup conflict (NIOSH-GJSQ: 3-15) & $7.2(2.9)$ & 0.87 & $6.5(2.9)$ & 0.87 & $<0.001$ \\
\hline Intergroup conflict (NIOSH-GJSQ: 3-15) & $6.6(3.0)$ & 0.87 & $5.7(2.7)$ & 0.89 & $<0.001$ \\
\hline Supervisor support (JCQ: 4-16) & $11.5(2.4)$ & 0.93 & $11.5(2.6)$ & 0.93 & 0.657 \\
\hline Co-worker support (JCQ: 4-16) & $11.6(2.0)$ & 0.85 & $12.0(1.9)$ & 0.84 & $<0.001$ \\
\hline Interactional justice (OJQ: 1-5) & $3.7(0.9)$ & 0.96 & $3.7(0.9)$ & 0.96 & 0.795 \\
\hline Psychological distress (K6: 0-24) & $3.9(5.0)$ & 0.93 & $4.2(4.9)$ & 0.92 & 0.306 \\
\hline
\end{tabular}

$\dagger \mathrm{SD}$ : standard deviation. ${ }^{\ddagger} p$ for sex difference of each demographic variable and scale score ( $t$-test or chi-square test). $\S \mathrm{NAQ}-\mathrm{R}$ : Negative Acts Questionnaire-Revised; LIPT: Leymann Inventory of Psychological Terror; NIOSH-GJSQ: National Institute for Occupational Safety and Health Generic Job Stress Questionnaire; JCQ: Job Content Questionnaire; OJQ: Organizational Justice Questionnaire.

$\mathrm{R}$ "weekly" or "daily" during the previous six months had significantly higher LIPT scores, higher intragroup and intergroup conflict, and higher psychological distress as well as lower supervisor and co-worker support, and lower interactional justice $(p<0.001)$.

\section{Prevalence of workplace bullying}

Table 5 presents the frequencies of each item in the NAQ-R. When operational criteria were used, a total of $9.0 \%$ of the participants reported at least one of the 22 negative acts of the NAQ-R weekly or more in the past six months. In addition, $5.9 \%$ endorsed the item of selflabeling as a victim of the NAQ-R and $0.7 \%$ were bullied on a weekly basis. On the other hand, $4.0 \%$ of the participants met the operational criteria for the LIPT, (i.e., at least one form of bullying weekly or more, and for at least six months in the past 12 months); $6.5 \%$ endorsed the item of self-labeling as a victim of the LIPT.

\section{Discussion}

The newly translated Japanese version of the NAQ-R showed an acceptable level of internal consistency reliability. Workplace bullying measured by the NAQ-R was highly correlated with workplace bullying measured by other scales, including the LIPT, and also with variables on interpersonal relations at work and psychological distress in the theoretically expected directions, supporting the concurrent and construct validity of the scale.

The NAQ-R had high Cronbach's alpha coefficients of 0.95 and 0.91 for males and females, respectively, indicating high internal consistency for the Japanese version of this scale. These coefficients are similar to or even higher than those reported in previous studies ${ }^{8,24)}$. This suggests the Japanese version of the NAQ-R has a level of reliability comparable to that of the European version.

The total score on the NAQ-R positively correlated with the two indicators of being a victim of workplace bullying measured as part of the NAQ-R and the LIPT. This finding is consistent with a previous study that reported the total score of the NAQ-R was strongly correlated with the perception of being a victim of workplace bullying $(r=0.54, p<0.001)^{21)}$. Scores of the NAQ-R seem to increase parallel to the frequency of labeling oneself as a victim of bullying, although self- 
Table 2. Exploratory factor analysis of 22 items of the NAQ-R using the maximum likelihood method and promax rotation among 1,626 civil servants in Japan

\begin{tabular}{|c|c|c|c|c|}
\hline Item & Item wording & Factor 1 & Factor 2 & Factor 3 \\
\hline \multicolumn{5}{|c|}{ Factor 1: Person- and work-related bullying } \\
\hline 8 & Being shouted at or being the target of spontaneous anger (or rage) (i) (p') & 0.80 & -0.05 & -0.06 \\
\hline 13 & Persistent criticism of your work and effort (p) (p') & 0.77 & 0.09 & -0.07 \\
\hline 2 & Being humiliated or ridiculed in connection with your work (p) (p') & 0.72 & -0.11 & 0.11 \\
\hline 7 & $\begin{array}{l}\text { Having insulting or offensive remarks made about your person (i.e. habits } \\
\text { and background), your attitudes or your private life (p) (p') }\end{array}$ & 0.62 & 0.21 & -0.08 \\
\hline 14 & Having your opinions and views ignored (w) (w') & 0.62 & -0.03 & 0.23 \\
\hline 20 & Being the subject of excessive teasing and sarcasm (p) (p') & 0.59 & 0.31 & -0.12 \\
\hline 11 & Repeated reminders of your errors or mistakes (p) (p') & 0.58 & 0.24 & -0.06 \\
\hline 17 & Having allegations made against you (p) (p') & 0.57 & 0.26 & -0.00 \\
\hline 12 & Being ignored or facing a hostile reaction when you approach (p) (p') & 0.56 & 0.13 & 0.05 \\
\hline 1 & Someone withholding information which affects your performance (w) (w') & 0.56 & -0.32 & 0.36 \\
\hline 18 & Excessive monitoring of your work (w) (w') & 0.56 & 0.08 & 0.08 \\
\hline 5 & Spreading of gossip and rumors about you (p) (p') & 0.54 & 0.23 & 0.02 \\
\hline 9 & $\begin{array}{l}\text { Intimidating behavior such as finger-pointing, invasion of personal space, } \\
\text { shoving, blocking/barring the way (i) (p') }\end{array}$ & 0.49 & 0.32 & -0.03 \\
\hline 21 & Being exposed to an unmanageable workload (w) (w') & 0.45 & -0.01 & 0.08 \\
\hline 16 & Being given tasks with unreasonable or impossible targets or deadlines (w) (w') & 0.44 & 0.01 & 0.22 \\
\hline 19 & $\begin{array}{l}\text { Pressure not to claim something which by right you are entitled to (e.g. sick leave, } \\
\text { holiday entitlement, travel expenses) (w) (w') }\end{array}$ & 0.35 & 0.17 & 0.06 \\
\hline 6 & Being ignored, excluded or being "sent to Coventry" (p) (p') & 0.31 & 0.21 & 0.30 \\
\hline
\end{tabular}

Factor 2: Physical or psychological intimidation bullying

\begin{tabular}{llrrr}
\hline 10 & Hints or signals from others that you should quit your job (p) (p') & -0.02 & $\mathbf{0 . 8 3}$ & 0.03 \\
22 & Threats of violence or physical abuse or actual abuse (i) & -0.08 & $\mathbf{0 . 7 5}$ & 0.07 \\
15 & Practical jokes carried out by people you don't get on with (p) (p') & 0.22 & $\mathbf{0 . 4 8}$ & 0.07
\end{tabular}

Factor 3: Occupational devaluation

\begin{tabular}{rlrr}
\hline 4 & & & \\
& Having key areas of responsibility removed or replaced with more trivial or \\
unpleasant tasks (p) (w') & -0.08 & 0.15 & $\mathbf{0 . 8 0}$ \\
$3 \quad$ Being ordered to do work below your level of competence (w) (w') & -0.00 & 0.06 & $\mathbf{0 . 7 3}$ \\
\hline Variance explained (\%) & 44.8 & 3.9 & 2.7 \\
\hline
\end{tabular}

(w): Work-related bullying; (p): Person-related bullying; (i): Physically intimidating bullying, according to Einarsen, Hoel, and Notelaers, 2009. (w’): Work-related bullying; (p'): Person-related bullying, according to Einarsen \& Hoel, 2001. Bold figures indicate factor loadings greater than 0.30 .

labeling as a victim of bullying may be related to factors other than exposure to bullying behaviors ${ }^{21)}$. The NAQ$\mathrm{R}$ score was also strongly and positively correlated with the LIPT score, suggesting that NAQ-R and LIPT measure an identical phenomenon, workplace bullying. These findings support the concurrent validity of the Japanese version of NAQ-R.

The findings of the present study also support the construct validity of this scale. For instance, high NAQ$\mathrm{R}$ total scores were correlated high psychological distress. This finding is consistent with a previous study that reported that scores on the NAQ-R were correlated with poor mental health ${ }^{21)}$. High NAQ-R scores were also correlated with high intragroup and intergroup conflict, low supervisor and co-worker support, and low interactional justice. These patterns were replicated in similar analyses comparing average scores of these scales by a dichotomous category of workplace bullying measured by NAQ-R. These findings are in expected directions, and also concordant with the fact that NAQ$\mathrm{R}$ correlated with high work pressure from workload, poor organizational climate, high stress from relationships with 
Table 3. Pearson's correlation coefficients between the total score of NAQ-R and workplace bullying measured by other scales, interpersonal relations at work, and psychological distress among 1,626 civil servants in Japan

\begin{tabular}{lcc}
\hline Scales $^{\dagger}$ & Crude & Sex and age-adjusted \\
\hline Self-labeling as a victim (NAQ-R) ${ }^{\ddagger}$ & 0.58 & 0.58 \\
Self-labeling as a victim (LIPT) ${ }^{\ddagger}$ & 0.49 & 0.49 \\
The number of bullying behavior (LIPT) & 0.77 & 0.77 \\
Group conflict: NIOSH-GJSQ & & \\
$\quad$ Intragroup conflict & 0.30 & 0.30 \\
$\quad$ Intergroup conflict & 0.33 & 0.33 \\
Worksite social support: JCQ & & \\
$\quad$ Supervisor support & -0.33 & -0.33 \\
$\quad$ Co-worker support & -0.26 & -0.26 \\
Interactional justice: OJQ & -0.35 & -0.35 \\
Psychological distress: K6 & 0.48 & 0.48 \\
\hline
\end{tabular}

$\dagger$ NAQ-R: Negative Acts Questionnaire-Revised; LIPT: Leymann Inventory of Psychological Terror; NIOSH-GJSQ: National Institute for Occupational Safety and Health Generic Job Stress Questionnaire; JCQ: Job Content Questionnaire; OJQ: Organizational Justice Questionnaire. $¥ 0=$ no, 1 =yes. All correlation coefficients are significant $(p<0.001)$.

Table 4. Comparisons of the number of victims of bullying and average scores of workplace bullying, interpersonal relations at work, and psychological distress between participants who had experienced at least one negative act weekly or daily (targets of bullying) and that of monthly or less (no target) assessed by NAQ-R among 1,626 civil servants in Japan

\begin{tabular}{|c|c|c|c|c|c|}
\hline \multirow[b]{2}{*}{ Scale scores $\S$} & \multicolumn{2}{|c|}{ Targets of bullying $(\mathrm{N}=146)$} & \multicolumn{2}{|c|}{ No target $(\mathrm{N}=1,480)$} & \multirow{2}{*}{$\begin{array}{c}\text { Adjusted } \\
p \text { value }\end{array}$} \\
\hline & Average $(\mathrm{SD})^{\dagger}$ & $\mathrm{n}(\%)$ & Average $(\mathrm{SD})^{\dagger}$ & $\mathrm{n}(\%)$ & \\
\hline \multicolumn{6}{|l|}{ Workplace bullying: LIPT } \\
\hline Total score $(0-45)$ & $7.4(8.1)$ & & $0.6(2.1)$ & & $<.001$ \\
\hline Leymann definition $\|$ & & $36(24.7)$ & & $29(2.0)$ & $<.001$ \\
\hline Self-labeling as a victim II & & $46(31.5)$ & & $60(4.1)$ & $<.001$ \\
\hline \multicolumn{6}{|l|}{ Group conflict: NIOSH-GJSQ } \\
\hline Intragroup conflict & $9.0(3.1)$ & & $6.6(2.8)$ & & $<.001$ \\
\hline Intergroup conflict & $8.5(3.3)$ & & $5.9(2.7)$ & & $<.001$ \\
\hline \multicolumn{6}{|l|}{ Worksite social support: JCQ } \\
\hline Supervisor support & $9.5(3.1)$ & & $11.7(2.3)$ & & $<.001$ \\
\hline Co-worker support & $10.5(2.7)$ & & $11.9(1.8)$ & & $<.001$ \\
\hline Interactional justice: OJQ & $3.0(1.1)$ & & $3.8(0.9)$ & & $<.001$ \\
\hline Psychological distress: K6 & $9.7(7.0)$ & & $3.5(4.3)$ & & $<.001$ \\
\hline
\end{tabular}

$\lceil$ SD: standard deviation. $¥$ Adjusted for sex and age. § LIPT: Leymann Inventory of Psychological Terror; NIOSH-GJSQ: National Institute for Occupational Safety and Health Generic Job Stress Questionnaire; JCQ: Job Content Questionnaire; OJQ: Organizational Justice Questionnaire. || Leymann definition: 1) exposure to at least one form of bullying behavior listed in the LIPT within the previous $12 \mathrm{mo}, 2$ ) weekly or more, and 3) for at least 6 mo. II Self-labeling as a victim: the number of people who answered they were victims of bullying.

colleagues, low organizational commitment, and low organizational satisfaction in a previous study ${ }^{21)}$, as well as that interactional injustice is a strong predictor of workplace aggression ${ }^{39,40)}$.

From the exploratory factor analysis of the 22 NAQ-R items, three factors were extracted. This factor structure differs slightly from the three-factor structure of NAQ previously reported ${ }^{21)}$. The extracted Factor 1 consisted of both person-related and work-related bullying ${ }^{21)}$, possibly because the respondents perceived these aspects closely together. Factor 2 in this study seems to consist of items of severe forms of bullying, which previously 
Table 5. Percentage of endorsed items on the NAQ-R among civil servants in Japan $(N=1,626)$

\begin{tabular}{|c|c|c|c|c|}
\hline $\begin{array}{l}\text { During the last } 6 \text { months, how often have you been subjected to the } \\
\text { following negative acts in the work place? }\end{array}$ & $\begin{array}{c}\text { Never } \\
(\%)\end{array}$ & $\begin{array}{l}\text { Now and } \\
\text { then }(\%)\end{array}$ & $\begin{array}{c}\text { Monthly } \\
(\%)\end{array}$ & $\begin{array}{l}\text { Weekly/ } \\
\text { daily* (\%) }\end{array}$ \\
\hline 1) Someone withholding information which affects your performance & 66.4 & 24.9 & 5.7 & 3.0 \\
\hline 2) Being humiliated or ridiculed in connection with your work & 83.0 & 13.2 & 2.0 & 1.9 \\
\hline 3) Being ordered to do work below your level of competence & 86.3 & 9.5 & 1.8 & 2.4 \\
\hline $\begin{array}{l}\text { 4) Having key areas of responsibility removed or replaced with more } \\
\text { trivial or unpleasant tasks }\end{array}$ & 89.9 & 7.6 & 1.3 & 1.2 \\
\hline 5) Spreading of gossip and rumors about you & 86.6 & 10.9 & 1.0 & 1.5 \\
\hline 6) Being ignored, excluded or being "sent to Coventry" & 90.7 & 6.9 & 1.0 & 1.3 \\
\hline $\begin{array}{l}\text { 7) Having insulting or offensive remarks made about your person (i.e. habit } \\
\text { and background), your attitudes or your private life }\end{array}$ & 87.1 & 10.3 & 1.1 & 1.4 \\
\hline 8) Being shouted at or being the target of spontaneous anger (or rage) & 85.2 & 11.3 & 2.5 & 1.1 \\
\hline $\begin{array}{l}\text { 9) Intimidating behavior such as finger-pointing, invasion of personal space } \\
\text { shoving, blocking/barring the way }\end{array}$ & 93.5 & 4.4 & 1.2 & 0.9 \\
\hline 10) Hints or signals from others that you should quit your job & 96.4 & 3.0 & 0.4 & 0.2 \\
\hline 11) Repeated reminders of your errors or mistakes & 88.3 & 9.8 & 1.2 & 0.8 \\
\hline 12) Being ignored or facing a hostile reaction when you approach & 90.3 & 6.8 & 1.2 & 1.7 \\
\hline 13) Persistent criticism of your work and effort & 88.2 & 8.9 & 1.9 & 1.0 \\
\hline 14) Having your opinions and views ignored & 82.5 & 14.1 & 1.8 & 1.6 \\
\hline 15) Practical jokes carried out by people you don't get on with & 94.9 & 3.9 & 0.6 & 0.6 \\
\hline 16) Being given tasks with unreasonable or impossible targets or deadlines & 85.2 & 12.4 & 1.4 & 1.0 \\
\hline 17) Having allegations made against you & 92.5 & 6.0 & 1.2 & 0.3 \\
\hline 18) Excessive monitoring of your work & 90.6 & 6.6 & 0.8 & 2.1 \\
\hline $\begin{array}{l}\text { 19) Pressure not to claim something which by right you are entitled to } \\
\text { (e.g. sick leave, holiday entitlement, travel expenses) }\end{array}$ & 93.2 & 5.7 & 0.7 & 0.4 \\
\hline 20) Being the subject of excessive teasing and sarcasm & 94.0 & 4.3 & 1.0 & 0.8 \\
\hline 21) Being exposed to an unmanageable workload & 87.3 & 9.8 & 1.3 & 1.5 \\
\hline 22) Threats of violence or physical abuse or actual abuse & 98.6 & 1.2 & 0.2 & 0.1 \\
\hline Frequency of people who chose at least one item & & & 14.5 & 9.0 \\
\hline
\end{tabular}

* Response categories "about weekly" and "about daily" have been thrown together to make one category.

were classified as "person-related bullying" and "physical intimidation." ${ }^{21)}$ Factor 3 consisted of two items which could be interpreted as occupational devaluation, i.e., being given a less important task. Japanese employees may distinguish types of workplace bullying differently from those observed in Western countries. In the Japanese workplace, which is characterized by collectivism ${ }^{29,41)}$, people are expected to share values and responsibility. In such a workplace culture, being given a less important task may imply that a worker is being placed in a lower position in the workplace society and perceived as a sign of social exclusion from the workplace. However, Factor 1 explained most variance. The one factor structure fitted the data best for the Japanese version of the NAQ- ${ }^{22}$. Since none of the models tested in the study sufficiently fitted to the data, the factor structure of the NAQ-R needs to be reexamined in a larger and more diverse sample of employees, including private sector employees.

Nine percent of the participants were classified as targets of workplace bullying, according to the NAQ-R, having reported at least one of the 22 negative acts weekly or more in the past six months. This figure is within but at a lower end of the prevalence $(8-15 \%)$ reported based on NAQ- $\mathrm{R}^{8,9)}$. When subjective criteria were used, $5.9 \%$ felt subjected to bullying, and $0.7 \%$ were regularly bullied on a weekly basis. Previous studies reported a wide range of prevalence based on the subjective criteria: 4.6-26.8\% were bullied, and $0.6-10 \%$ were regularly bullied ${ }^{8,9,14,20)}$. The prevalence in this study is within the range of previous reports. Generally, the prevalence using the operational method is higher than that of subjective method ${ }^{5)}$, suggesting prevalence is underestimated if only the subjective method is used ${ }^{42)}$. This pattern was also observed in this study.

Finally, some possible limitations should be considered. First, the response rate was moderate, and a certain number of respondents who failed to fully complete the questionnaire were excluded. Participants who had an 
experience of workplace bullying may have been more likely to respond to the survey, which could result in overestimation of the prevalence. On the other hand, as "bullying" is a sensitive word for employees who have experienced bullying behavior in the past, they may have been reluctant to complete a questionnaire including such items. In fact, some participants wrote they could not complete the questionnaire because the items of the NAQ$\mathrm{R}$ reminded them of a past unhappy experience. In this case, the prevalence may have been underestimated. Second, the NAQ-R was developed in European countries, which may result in poor model fit in confirmatory factor analysis. The results of the present study suggest that negative acts listed in this scale are not appropriate for Japanese employees. For example, in item \#22 ("threats of violence or physical abuse or actual abuse"), the word "physical abuse" may have too strong a meaning, sounding like a crime in Japanese, and resulting in a biased response from respondents. In contrast, in Japan, apparently-unrelated bullying behavior is often likely to happen: e.g., "being ordered to do work below your level of competence" (item \#3). At the same time, Japanese culture has equalitarianism. Japanese people therefore are sensitive to differential treatment among employees within the company. At this point, the NAQ-R might be missing some items of negative acts originally experienced by Japanese workers. Further examination of the wording or the content of the NAQ-R is needed. Finally, the present study did not examine the test-retest reliability or concurrent validity using an objective assessment of workplace bullying, which should also be tested in a future study.

This study confirmed the internal consistency reliability and concurrent and construct validity of the newly developed Japanese version of the 22-item NAQ-R for the general working population using a sample of Japanese civil servants. This version of NAQ-R may be a useful measure to investigate the prevalence, associated factors, and impact on health of workplace bullying in Japan, which should contribute to identifying, controlling, and preventing workplace bullying.

Acknowledgments: The present study was supported by the Occupational Health Promotion Foundation, Japan. The authors are grateful to Prof. Ståle Einarsen, Dr. Morten Birkeland Nielsen, and Dr. Helge Hoel from the Bergen Bullying Research Group, who checked the backtranslation of the Japanese version of the NAQ-R.

\section{References}

1) Brodsky CM. The harassed worker. Toronto (Canada): Lexington Books; 1976.

2) Keashly L. Emotional abuse in the workplace: conceptual and empirical issues. J Emot Abuse 1998; 1: 85-117.
3) Leymann H. The content and development of mobbing at work. Eur J Work Organ Psychol 1996; 5: 165-84.

4) Einarsen S, Hoel H, Zapf D, Cooper CL. The concept of bullying at work. In: Einarsen S, Hoel H, Zapf D, Cooper CL, editors. Bullying and emotional abuse in the workplace: international perspectives in research and practice. London (UK): Taylor \& Francis; 2003. p.3-30.

5) Agervold M. Bullying at work: a discussion of definitions and prevalence, based on an empirical study. Scand J Psychol 2007; 48: 161-72.

6) Einarsen S, Raknes B. Harassment in the workplace and the victimization of man. Viol Victims 1997; 12: 247-63.

7) Einarsen S, Skogstad A. Bullying at work: epidemiological findings in public and private organizations. Eur J Work Organ Psychol 1996; 5: 185201.

8) Nielsen MB, Skogstad A, Matthiesen SB, et al. Prevalence of workplace bullying in Norway: comparisons across time and estimation methods. Eur J Work Organ Psychol 2009; 18: 81-101.

9) Zapf D, Einarsen S, Hoel H, Vartia M. Empirical findings on bullying in the workplace. In: Einarsen S, Hoel H, Zapf D, Cooper CL, editors. Bullying and emotional abuse in the workplace: international perspectives in research and practice. London (UK): Taylor \& Francis; 2003. p.103-26.

10) Niedhammer I, David S, Degioanni S. Association between workplace bullying and depressive symptoms in the French working population. J Psychosom Res 2006; 61: 251-9.

11) Nielsen MB, Matthiesen SB, Einarsen S. Sense of coherence as a protective mechanism among targets of workplace bullying. J Occup Health Psychol 2008; 13: $128-36$.

12) Mikkelsen EG, Einarsen S. Relationships between exposure to bullying at work and psychological and psychosomatic health complaints: the role of state negative affectivity and generalized self-efficacy. Scand J Psychol 2002; 43: 397-405.

13) Kivimäki M, Leino-Arjas P, Virtanen M, et al. Work stress and incidence of newly diagnosed fibromyalgia: prospective cohort study. J Psychosom Res 2004; 57 : 417-22.

14) Vartia MA. Consequences of workplace bullying with respect to the well-being of its targets and the observers of bullying. Scand J Work Environ Health 2001; 27: 63-9.

15) Niedhammer I, Chastang JF, David S. Importance of psychosocial work factors on general health outcomes in the national French SUMER survey. Occup Med 2008; 58: 15-24.

16) Vingård E, Lindberg $P$, Josephson $M$, et al. Long-term sick-listing among women in the public sector and its associations with age, social situation, lifestyle, and work factors: a three-year follow-up study. Scand J Public Health 2005; 33: 370-5.

17) Einarsen S. Harassment and bullying at work: a review of the Scandinavian approach. Aggress Viol Behav 
2000; 5: 379-401.

18) Mikkelsen EG, Einarsen S. Bullying in Danish worklife: prevalence and health correlates. Eur J Work Organ Psychol 2001; 10: 393-413.

19) Einarsen S, Hoel H. The Negative Acts Questionnaire: development, validation and revision of a measure of bullying at work. Paper presented at the 10th European congress on work and organisational psychology. Prague (Czech Republic): 10th European congress on work and oganizational psychology; 2001.

20) Hoel H, Cooper CL, Faragher EB. The experience of bullying in Great Britain: the impact of organizational status. Eur J Work Organ Psychol 2001; 10: 443-65.

21) Einarsen $S$, Hoel H, Notelaers G. Measuring exposure to bullying and harassment at work: validity, factor structure and psychometric properties of the Negative Acts Questionnaire-Revised. Work Stress 2009; 23: 24 44.

22) Einarsen $S$, Raknes B. Mobbing i arbeidslivet [Bullying in working life]. Bergen (Norway): Universitetet $\mathrm{i}$ Bergen; 1991 (in Norsk).

23) Hoel H, Faragher B, Cooper CL. Bullying is detrimental to health, but all bullying behaviours are not necessarily equally damaging. Br J Guid Counsell 2004; 32: 367-87.

24) Hauge LJ, Skogstad A, Einarsen S. Relationships between stressful work environments and bullying: results of a large representative study. Work Stress 2007; 21: 220-42.

25) Salin D. Prevalence and forms of bullying among business professionals: a comparison of two different strategies for measuring bullying. Eur J Work Organ Psychol 2001; 10: 425-41.

26) Quine L. Workplace bullying in NHS community trust: staff questionnaire survey. BMJ 1999; 318: 228-32.

27) Abe K. Hierarchical models of workplace bullying among Japanese hospital nurses. Thesis (Ph.D.). Twin Cities (MN): University of Minnesota; 2007.

28) Takaki J, Tsutsumi A, Fujii Y, et al. Assessment of workplace bullying and harassment: reliability and validity of a Japanese version of the Negative Acts Questionnaire. J Occup Health 2010; 52: 74-81.

29) Nakane C. Japanese society. Berkeley (CA): University of California Press; 1970.

30) Hofstede G. Cultures and organizations. New York:
McGraw-Hill; 1991. p.139-58.

31) Brooks L, Perot AR. Reporting sexual harassment: exploring a predictive model. Psychol Women Q 1991; 15: 31-47.

32) Kessler RC, Andrews G, Colpe LJ, et al. Short screening scales to monitor population prevalences and trends in non-specific psychological distress. Psychol Med 2002; 32: 959-76.

33) Inoue A, Kawakami N, Tsutsumi A, et al. Reliability and validity of the Japanese version of the Organizational Justice Questionnaire. J Occup Health 2009; 51:74-83.

34) Elovainio M, Kivimäki M, Vahtera J. Organizational justice: evidence of a new psychosocial predictor of health. Am J Public Health 2002; 92: 105-8.

35) Moorman RH. Relationship between organizational justice and organizational citizenship behaviors: do fairness perceptions influence employee citizenship? J Appl Psychol 1991; 76: 845-55.

36) Hurrell JJ Jr, McLaney MA. Exposure to job stress-a new psychometric instrument. Scand J Work Environ Health 1998; 14(Suppl): 27-8.

37) Karasek R. Job Content Questionnaire and user's guide. Lowell (MA): University of Massachusetts at Lowell; 1985.

38) $\mathrm{Hu} \mathrm{L}$, Bentler PM. Cutoff criteria for fit indexes in covariance structural analysis: conventional criteria versus new alternatives. Struct Equ Model 1999; 6: 155.

39) Hershcovis S, Barling J. Preventiong workplace violence. In: Kelloway EK, Barling J, Hurrell J. Handbook of workplace violence. Thousad Oaks (CA) :Sage Publications; 2006. p. 607-32.

40) Ladebo OJ, Awotunde JM, AbdulSalaam-Saghir P. Coworkers' and supervisor interactional justice: correlates of extension personnel's job satisfaction, distress, and aggressive behavior. J Behav Appl Manag 2008; 9: 206-25.

41) Markus H, Kitayama S. Culture and the self: implications for cognition, emotion, and motivation. Psychol Rev 1991; 98: 224-53.

42) Notelaers G, Einarsen S, Witte HD, Vermunt JK. Measuring exposure to bullying at work: the validity and advantages of the latest class cluster approach. Work Stress 2006; 20: 289-302. 
Appendix: The Japanese Version of the Negative Acts Questionnaire-Revised

以下に示すものは、職場でたびたび見かけられるネガティブな言動の例です。 あなたは、以下のような言動を、どのくらいの頻度で経験しましたか。

過去 6ヶ月間にあなた自身が経験した頻度に、

もつとも近い数字に○をつけてください。

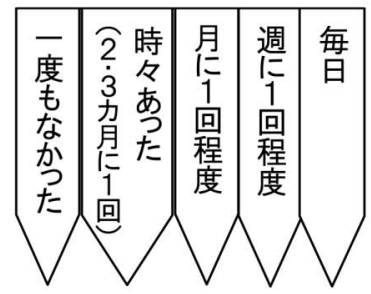
1） あなたが仕事をする上で影響を及ぼすような情報を与えてもらえなかった
2） 仕事に関することで想をかかされた、あるいは、からかわれた
3） あなたの能力·力量よりも低い仕事を与えられた

$\begin{array}{lllll}1 & 2 & 3 & 4 & 5\end{array}$

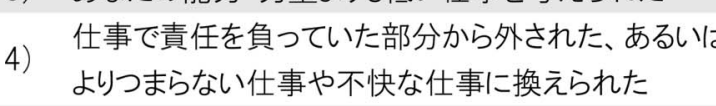
$\begin{array}{lllll}1 & 2 & 3 & 4 & 5\end{array}$
5）あなたに関する陰口や噂を広められた
6）あなたがいないかのように振る舞われた、のけものにされた、もしくは仲間外れにされた あなた自身のこと(習慣や生い立ち)やあなたの振る舞い、
7） あるいは私生活について、ばかにされたり、失礼なことを言われた

12345
8）怒鳴られた、あるいは、いきなり怒り(もしくは激怒)の矛先を向けられた
9）非難される、パーソナルスペース(個人の空間)に立ち入られる、 押しのけられる、道をふさがれる、といつたような威圧的な行為を受けた
10）仕事を辞めるべきだとほのめかされた、もしくは態度で示された
11）あなたが起こした間違いや誤りを、繰り返し思い出させられた
12）あなたが近づいたとき、無視されたり、敵意を持った反応をされた
13）あなたの仕事や努力に対して、何度も批判された
14）あなたの意見や考えが無視された
15）あなたとうまの合わない人から、悪質ないたずらをされた $\begin{array}{lllll}1 & 2 & 3 & 4 & 5\end{array}$
16) 納得がいかない、もしくはやり遂げることが不可能な目標や締め切りを 設定された仕事を与えられた
17）根拠なく非難された
18）必要以上に仕事を監視された あなたに権利のあるもの(例えば疾病休業の申し出、休暇の取得、
19）交通費の支給など)を主張できないよう、圧力をかけられた

$\begin{array}{lllll}1 & 2 & 3 & 4 & 5\end{array}$

$\begin{array}{lllll}1 & 2 & 3 & 4 & 5\end{array}$

$\begin{array}{lllll}1 & 2 & 3 & 4 & 5\end{array}$
20）度が過ぎた からかいや嫌みを言われる対象となった
21）手に負えないくらい沢山の仕事を与えられた
22）暴力や、身体的な虐待を受ける恐れがあった。もしくは、実際に被害を受けた

$\begin{array}{lllll}1 & 2 & 3 & 4 & 5\end{array}$

$\begin{array}{lllll}1 & 2 & 3 & 4 & 5\end{array}$

$\begin{array}{lllll}1 & 2 & 3 & 4 & 5\end{array}$

$\begin{array}{lllll}1 & 2 & 3 & 4 & 5\end{array}$

$\begin{array}{lllll}1 & 2 & 3 & 4 & 5\end{array}$

$\begin{array}{lllll}1 & 2 & 3 & 4 & 5\end{array}$

$\begin{array}{lllll}1 & 2 & 3 & 4 & 5\end{array}$

$\begin{array}{lllll}1 & 2 & 3 & 4 & 5\end{array}$

$\begin{array}{lllll}1 & 2 & 3 & 4 & 5 \\ 1 & 2 & 3 & 4 & 5\end{array}$

$\begin{array}{lllll}1 & 2 & 3 & 4 & 5 \\ 1 & 2 & 3 & 4 & 5 \\ 1 & 2 & 3 & 4 & 5 \\ 1 & 2 & 3 & 4 & 5 \\ 1 & 2 & 3 & 4 & 5 \\ 1 & 2 & 3 & 4 & 5\end{array}$

\section{職場の「いじめ」についておたずねします。}

ここでは「いじめ」を「特定の個人もしくは複数の人が、1 人もしくは複数の人から、一定期間にわたって継続的に好ましくない 行為を受けていると感じながらも、これらの行為から自分を守ることが難しい状況」と定義します。

1 回限りの出来事は含めません。

23）あなたは、職場でいじめにあったことがありますか？

この定義を用いたとき、過去 6ヶ月間に職場で 1 .

2.はい、

3.はい、

4.はい、

5.はい、

いじめを受けたことがあるか、最もあてはまるも

いいえ

ほんのまれに 時々

週に何回か

ほぼ毎日

のに○をつけてください 